\title{
New Pliocene Rhinocerotidae findings from the Iberian Peninsula and the revision of the Spanish Pliocene records
}

\author{
Luca Pandolfi $^{1}$ (D) . Joaquín Sendra ${ }^{2} \cdot$ Matías Reolid $^{3}$ (D) $\cdot$ Lorenzo Rook $^{1}$ (D)
}

Received: 17 May 2021 / Accepted: 30 December 2021 / Published online: 21 January 2022

(c) The Author(s) 2022

\begin{abstract}
A fragmentary mandible from the early Pliocene of the Vera Basin is here investigated to clarify its taxonomic position. The studied specimen is here assigned to Pliorhinus megarhinus, documented in Europe from the latest Miocene to the midPliocene. The morphometrical comparison reveals that this taxon is larger than Stephanorhinus etruscus and S. jeanvireti but overlaps with Dihoplus schleiermacheri. P. megarhinus and D. schleiermacheri differ in some characters of the lower molars, such as the length of the metalophid and the shape of the trigonid in occlusal view, thus allowing new considerations on the Pliocene Spanish rhinocerotine record. According to the results here obtained, three species are at least documented in Span during the Pliocene: P. megarhinus, P. miguelcrusafonti, and S. etruscus. The presence of S. jeanvireti has to be verified and confirmed by further evidence. The presence of Dihoplus schleiermacheri as a relict taxon in the Pliocene of Spain is here discarded.
\end{abstract}

Keywords Pliocene $\cdot$ Spain $\cdot$ Morphology $\cdot$ Morphometry $\cdot$ Biochronology

\section{Introduction}

Although the family Rhinocerotidae was widely distributed in Eurasia during the Neogene (Geraads et al. 2020), Pliocene rhinocerotine record is still poorly understood in respect to Miocene one, being usually documented by few localities and scanty remains (Pandolfi et al. 2020).

Handling Editor: Thomas Mörs.

\section{Luca Pandolfi}

luca.pandolfi@unifi.it

Joaquín Sendra

joaquin.r.sendra@uv.es

Matías Reolid

mreolid@ujaen.es

Lorenzo Rook

lorenzo.rook@unifi.it

1 Dipartimento di Scienze della Terra, Paleo[Fab]Lab, Università di Firenze, Via G. La Pira 4, 50121 Florence, Italy

2 Instituto Cavanilles de Biodiversidad y Biología Evolutiva, Universidad de Valencia, 46071 Valencia, Spain

3 Departamento de Geología, Universidad de Jaén, Campus Las Lagunillas sn, 23071 Jaén, Spain
During that time, only four taxa are recorded in Europe: Pliorhinus megarhinus, P. miguelcrusafonti, Stephanorhinus etruscus and S. jeanvireti (Guérin et al. 1969; Guérin 1972, 1980; Vekua 1972; Guérin and Santafé-Llopis 1978; Cerdeño 1992; Lacombat and Mörs 2008; Guérin and Tsoukala 2013; Pandolfi et al. 2017, 2019, 2020, 2021; Tsoukala 2018). The biochronological and geographic ranges of these taxa are far to be completely investigated and several records need to be deeply revised.

In the Iberian Peninsula, Spain in particular, the Pliocene rhinocerotine record is relatively scarce, and the material is usually represented by isolated remains. The systematic attribution of these specimens is controversial, and the occurrence of some species such as $S$. jeanvireti or $P$. megarhinus (Guérin 1980; Cerdeño 1992), as well as the persistence of the Miocene Dihoplus schleiermacheri (Montoya et al. 2006), still need to be confirmed or discarded.

The discovery of new rhinoceros remains from the early Pliocene of the Vera Basin (Southeast Spain), here described for the first time, raises the opportunity to revise the Pliocene Spanish rhinocerotine records. Accordingly, a first attempt to build up a new biochronological and paleobiogeographic framework of the Pliocene rhinocerotine species in Spain is reported. 


\section{Geological setting}

\section{The Vera Basin}

The studied specimen was recovered in a Neogene intramountain basin located in the eastern part of the Betic Cordillera, the Vera Basin (Fig. 1). This basin was open to the east to the Mediterranean Sea. The Vera Basin was also connected with other intramountain basins such as the Sorbas Basin to the south and the Lorca Basin to the north, through narrow corridors (Fig. 1). Since the Pliocene, this basin has been subjected to low uplift rates around 11-21 $\mathrm{m} \mathrm{Ma}^{-1}$ (Stokes 2008).

The Vera Basin is filled by marine and transitional deposits from the Burdigalian to Holocene. The studied remains
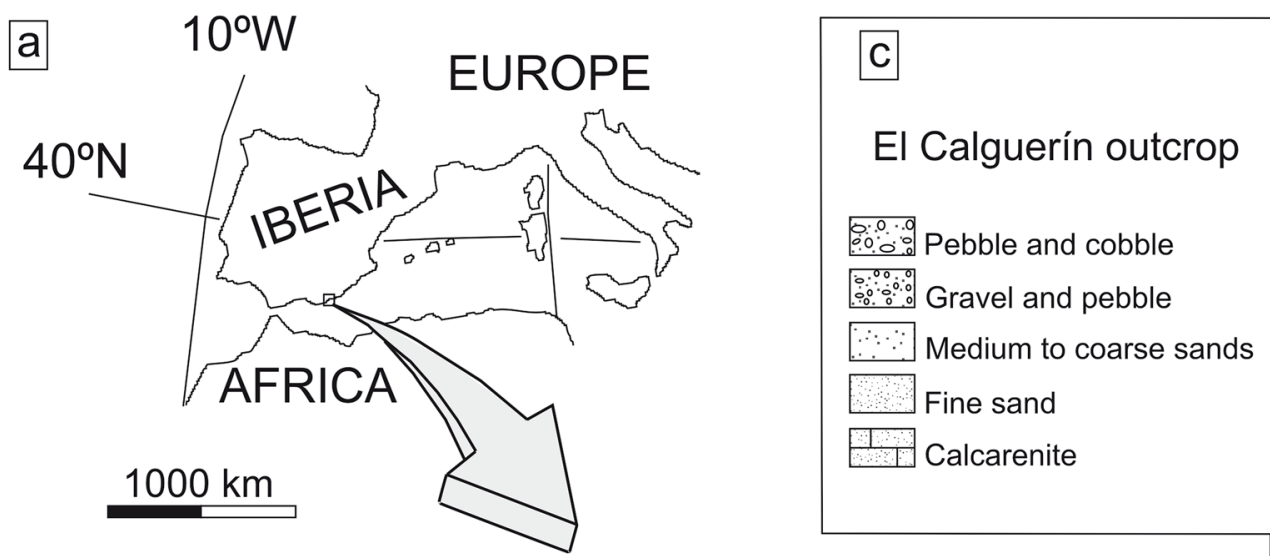

0.09 Pebble and cobble Gravel and pebble $\because$ Medium to coarse sands Fine sand Calcarenite

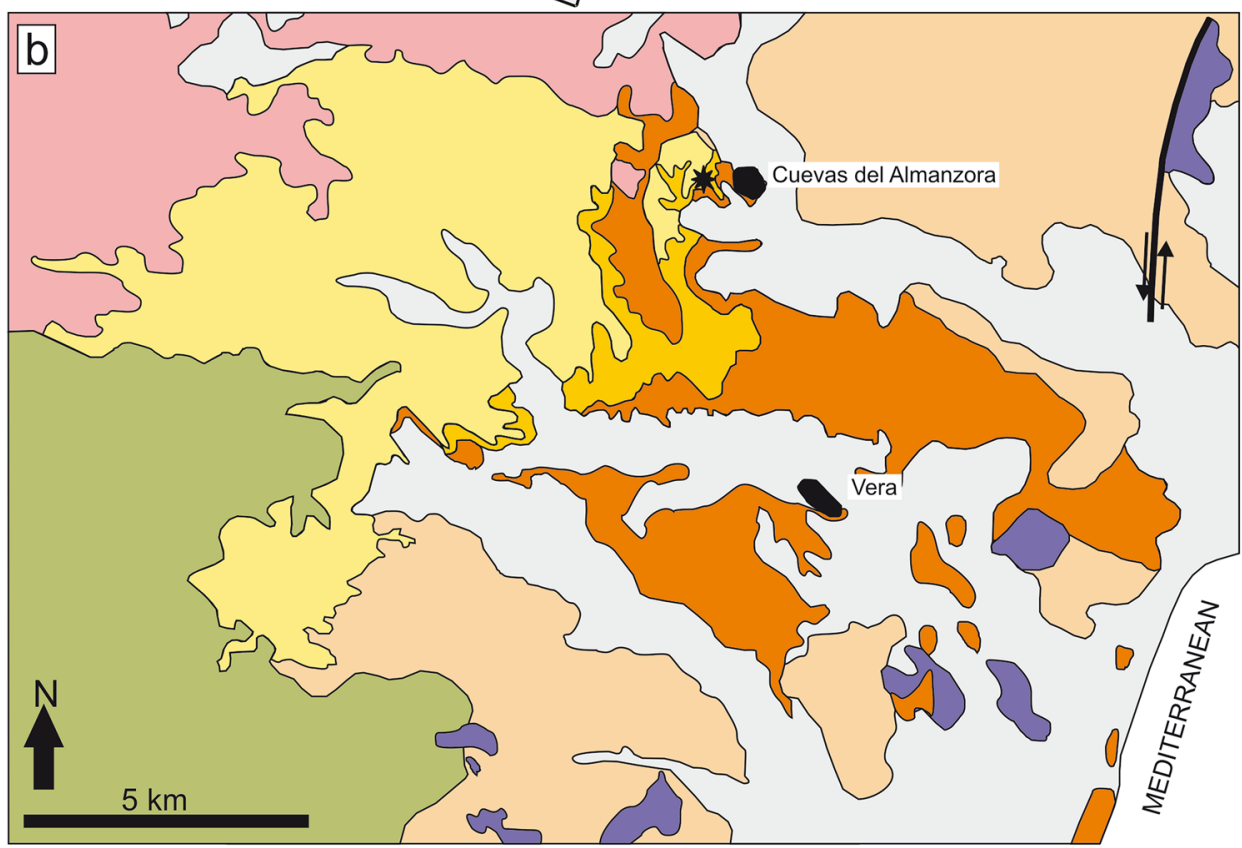

Metamorphic rocks

Permo-Triassic, Nevado Filabride Complex

Metamorphic rocks

Triassic, Alpujarride Complex

Volcanics, Upper Miocene

Upper Miocene,

Chozas and Turre formations
Lower-Mid Pliocene, Cuevas Formation

Mid-Upper Pliocene, Espiritu Santo Formation

Plio-Pleistocene, Salmerón Formation

Quaternary indiferentiated

El Calguerín outcrop

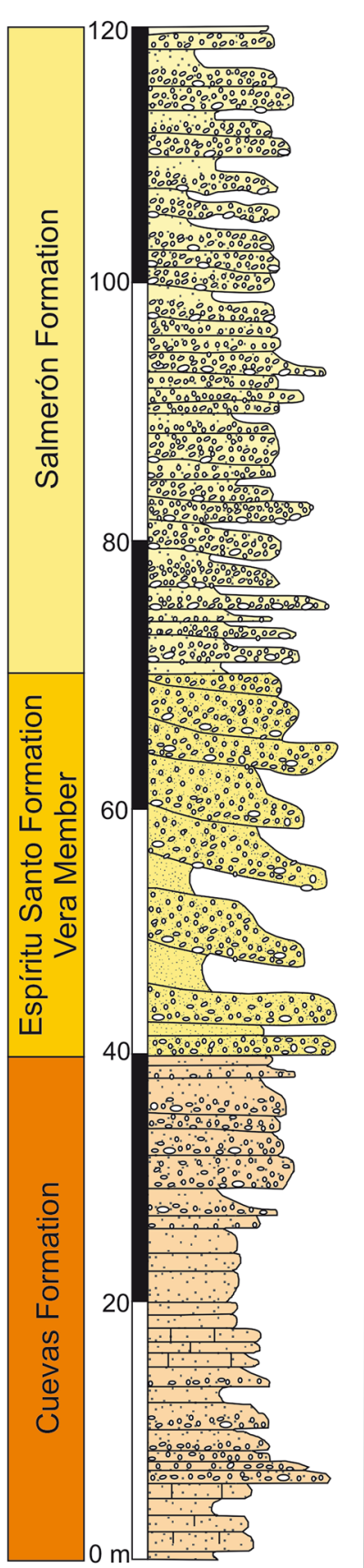

Fig. 1 Geological setting of the Vera basin. a Location of the Vera Basin; b Geological map of the Vera Basin with the distribution of the Cueva and Espiritu Santo Formation; c sedimentary log of the El Calguerín area. Modified from Sendra et al. (2020) 
are related to the sediments of a delta system that evolved to alluvial fan, developed during the Pliocene and Pleistocene (Stokes 2008; Sendra et al. 2020). Völk (1967) differentiated three formations: Cuevas Formation (lower Pliocene), Espiritu Santo Formation (middle to upper Pliocene), and Salmerón Formation (uppermost Pliocene and Quaternary).

The Cuevas Formation (lower Pliocene) is constituted by medium to coarse bioclastic sands (calcarenites) with conglomerate layers in the proximal areas that change into fine sands and silts in the center of the basin. The Espiritu Santo Formation (middle to upper Pliocene) consists of coarse sand and conglomerates in the margins of the basin that range to medium and fine sands and limestones in distal areas. The Salmerón Formation (uppermost Pliocene and Quaternary) is constituted by reddish conglomerates, sands, and red silts with calcretes. The Salmerón Formation represents the filling of the basin with continental alluvial-fan deposition.

The studied specimen was recovered in the northern margin of the Vera Basin and more exactly in the Cuevas Formation at the El Calguerín outcrop (coordinates $37^{\circ} 18^{\prime} 04^{\prime \prime} \mathrm{N}$, $1^{\circ} 53^{\prime} 03^{\prime \prime} \mathrm{W}$ ) close to the Cuevas del Almanzora locality, Almeria province.

The Cuevas Formation is characterized by yellow-beige bioclastic sandstones (calcarenites) and conglomerates (pebbles and cobbles) in the northern margin of the basin that grade to blue-gray mud-siltstones, silty marls and fine sandstones in the central basin areas. The thickness ranges from almost $200 \mathrm{~m}$ in the central part of the basin to less than $50 \mathrm{~m}$ in the northern margin. In northern and western regions, the Cuevas Formation unconformably onlaps metamorphic basement at the basin margins.

In the central area of the basin, the fine grain lithofacies (mudstones, siltstones, and fine sandstones) are commonly massive but locally with $\mathrm{cm}$-scale planar cross-stratification. The trace fossils (Ophiomorpha, Skolithos and Diplocraterion and less common Teichichnus) are abundant and macroinvertebrates include thin-shelled bivalves (Amusium cristatum, Aequipecten opercularis, Chlamys radians, Pecten benedictus, and Pecten jacobaeus), oysters, brachiopods (Terebratulla), gastropods (Turritella, conids and olivids) and irregular echinoids (Schizaster and Clypeaster) (Sendra et al. 2020). Völk (1967) and Ott d'Estevou et al. (1991) proposed an early-mid-Pliocene age for this formation based on the microfossil assemblages.

In the northern and western margins of the Vera Basin, the lithofacies of the Cuevas Formation are relatively coarse (medium to very coarse sands and sandstones, pebbly sandstones, and conglomerates) with well-bedded units with planar and cross-stratification (cm-scale). The sands and conglomerates are mainly metamorphic grains and dolostones clasts, with small pieces of wood $(<10 \mathrm{~cm})$ preserved as charcoal. Conglomerates show clast imbrication and graded-bedding (fining upwards) with erosive irregular base. Marine trace fossils are well preserved in sandstones. The bioclastic calcareous lens-shaped bodies pinch-out laterally (in less than $10 \mathrm{~m}$ long).

Some remains of fossil marine mammals have been previously recorded from the Cuevas Formation (see Sendra et al. 2020) such as sirenians (Family Dugongidae, genus Metaxytherium), and cetaceans such as Odontoceti (Family Delphinidae, genus Astadelphis) and Mysticeti (Family Balaenidae). In addition, some continental mammals have been recorded in the more proximal areas (Sendra et al. 2020), such as a hemimandible of Lynx issiodorensis, a molar of a deer, and a hemimandible of a rhinoceros which is the subject of this work. These continental remains were found in shallow coarse marine facies.

\section{Materials and methods}

The studied material is stored at MGUV. The dental nomenclature used in this paper is reported in Fig. 2. The morphometric methodology follows Guérin (1980: p. 66, p. 71) and Lacombat (2006: Fig. 43). The measurements of the considered specimens are reported in Supplementary data and Table 1. The studied specimen was acquired using the structured blue led light 3D Scanner Artec Space Spider. A downloadable 3D model is available as Supplementary Resource File.

\section{Anatomical abbreviations}

i-lower incisor; $\mathrm{m}$-lower molar.

\section{Morphometric abbreviations}

Lbm-length of the molar row, buccal side (= maximal length of the molar row in Guérin 1980; Lacombat 2006, Fig. 43).

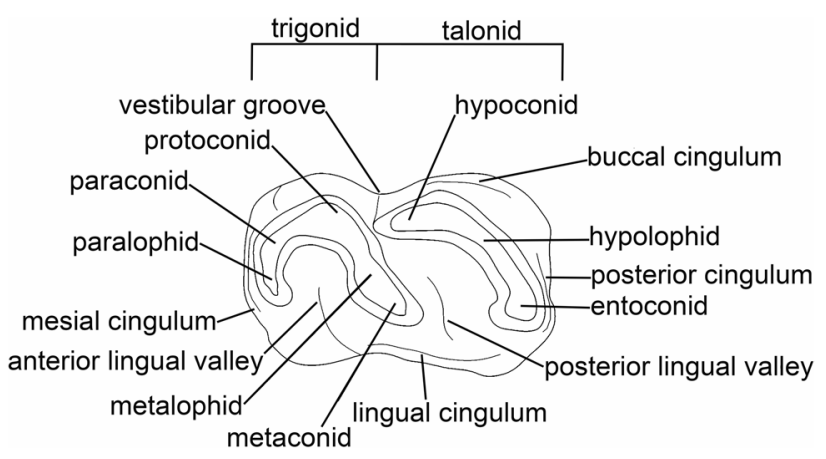

Fig. 2 Dental nomenclature of a rhinocerotine lower molar 
Table 1 Comparative measurements for the length of the molar row (Lbm) among the Pliocene-earliest Pleistocene European rhinoceroses

\begin{tabular}{|c|c|c|c|c|}
\hline Name & Lbm & Locality & ID & References \\
\hline Vera Basin & 156.47 & Vera Basin & MGUV 39018 & \\
\hline P. megarhinus & 142 & Fratesti & & Guérin et al. (1969) \\
\hline P. megarhinus & 149.5 & Gödollö & HNHM & \\
\hline P. megarhinus & 158 & Kávás & HNHM v.79.117 & \\
\hline P. megarhinus & 165 & Millas & & Guérin et al. (1969) \\
\hline P. megarhinus & $130-133$ & Monte Giogo & & Pandolfi (2013) \\
\hline P. megarhinus & 151.8 & Montpellier & NMB MP1031 & \\
\hline P. megarhinus & $131-163$ & Montpellier & & Guérin et al. (1969) \\
\hline P. megarhinus & 158.09 & Montpellier & NHMUK 40805 & \\
\hline P. megarhinus & 144.97 & Palaia & IGF13091 & \\
\hline P. megarhinus & $140-152$ & Saint Laurent & & Guérin et al. (1969) \\
\hline P. megarhinus & 139 & Val di Pugna & MSNAF4747 & \\
\hline D. schleiermacheri & 151.31 & Eppelsheim & NHMUK M2781 & \\
\hline D. schleiermacheri & 148.82 & Eppelsheim & NHMUK M2781 & \\
\hline D. schleiermacheri & 145.71 & Eppelsheim & NHMUK M2782 & \\
\hline D. schleiermacheri & 136.52 & Eppelsheim & NHMUK M3150 & \\
\hline D. schleiermacheri & 142.71 & Eppelsheim & NHMUK 21022 & \\
\hline D. schleiermacheri & 150 & Eppelsheim & NHMUK 21021 & \\
\hline D. schleiermacheri & 139 & Venta del Moro & MNCN 10977 & Estimated from Morales (1984) \\
\hline S. etruscus & 123.6 & Aivaliki & & Pandolfi and Erten (2017) \\
\hline S. etruscus & 130 & Capitone & & Pandolfi et al. (2015) \\
\hline S. etruscus & 122.5 & Castellana & & Pandolfi and Erten (2017) \\
\hline S. etruscus & 135 & Monte delle Piche & & Pandolfi et al. (2015) \\
\hline S. etruscus & $125-134$ & Montevarchi & & Mazza (1988) \\
\hline S. etruscus & $127.1-132$ & Pietrafitta & & Pandolfi et al. (2017) \\
\hline S. etruscus & $122.09-122.7$ & Senèze & & Lacombat (2006) \\
\hline S. etruscus & $118-131$ & Upper Valdarno & IGF755 & Mazza (1988) \\
\hline S. jeanvireti & 133.15 & Capannoli & IGF1449v & \\
\hline S. jeanvireti & $133-140$ & Milia & & Guérin and Tsoukala (2013) \\
\hline S. jeanvireti & 128 & Monte Pulgnasco & MGC9352 & \\
\hline S. jeanvireti & 138.9 & Monte San Pietro & MGC9354 & \\
\hline S. jeanvireti & $131-138$ & Vialette & & Guérin (1972) \\
\hline
\end{tabular}

\section{Institutional abbreviations}

HNHM-Magyar Természettudományi Múzeum, Budapest, Hungary; IGF-Museo di Storia Naturale, sezione di Geologia e Paleontologia, Università degli Studi di Firenze, Florence, Italy; MFS, Museo Civico di Scienze Naturali, Faenza, Italy; MGC-Museo di Geologia G. Capellini, Università di Bologna, Italy; MGUV_-Museu de Geologia de la Universitat de València, Valencia, Spain; ML-Musée Guimet d'Histoire Naturelle de Lyon, Lyon, France; MNCN-Museo Nacional de Ciencias Naturales, Madrid, Spain; MNHN-Muséum National d'Histoire Naturelle, Paris, France; MSNAF-Museo di Storia Naturale, Accademia dei Fisiocritici, Siena, Italy; NHMUKNatural History Museum, London, UK; NMB-Naturhistorisches Museum, Basel, Switzerland.

\section{Systematic paleontology}

Order Perissodactyla Owen, 1848

Family Rhinocerotidae Gray, 1821

Subfamily Rhinocerotinae Gray, 1821

Tribe Rhinocerotini Gray, 1821

Subtribe Rhinocerotina Gray, 1821

Genus Pliorhinus Pandolfi et al., 2021

Type species: Pliorhinus megarhinus (de Christol 1834) from the Pliocene of Montpellier, France.

Other species: Pliorhinus miguelcrusafonti (Guérin and Santafé-Llopis 1978). 
Fig. 3 Rhinocerotidae specimen from Vera basin, MGUV 39018. a Occlusal view of the mandible with $\mathrm{m} 1-\mathrm{m} 2$, b lingual view of the mandible with $\mathrm{m} 1-\mathrm{m} 2$, c occlusal, lingual and buccal views of $\mathrm{m} 1$

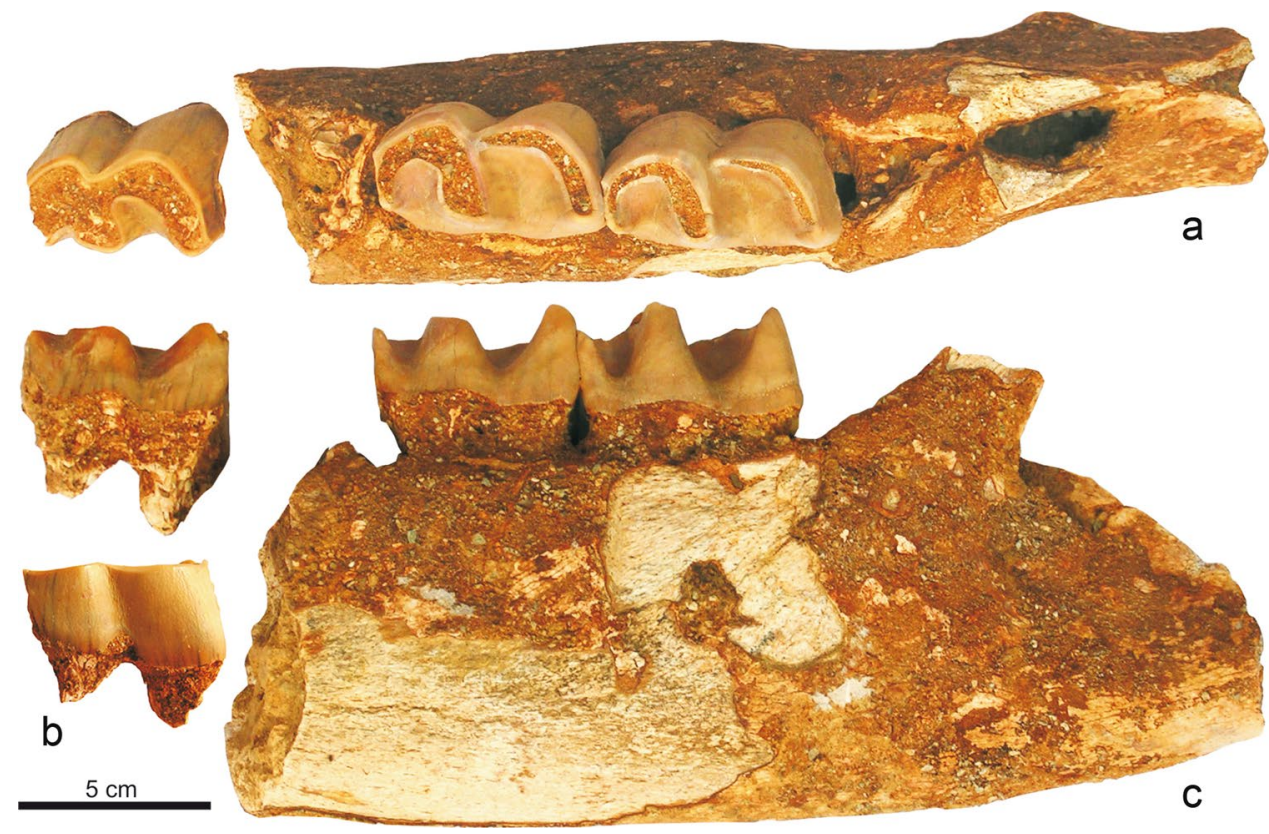

Pliorhinus megarhinus (de Christol 1834).

Figure 3.

Material: A fragmentary right hemimandible with the molar row (39018) housed at MGUV.

Description: The specimen MGUV 39018 is a fragment of the right mandibular corpus with the molar row (Fig. 3). The specimen belongs to an adult individual with $\mathrm{m} 3$ fully erupted and slightly worn. Vestibular cingula are absent on $\mathrm{m} 1$ and $\mathrm{m} 3$ whilst $\mathrm{m} 2$ has a reduced mesial-vestibular cingulum. The vestibular groove is opened and shallow and reaches the neck on all the molars. A small distal cingulum is present on all the teeth. In occlusal view, the paralophid reaches the lingual rim. In the same view, the trigonid forms an obtuse dihedron. The anterior and posterior lingual valleys are U-shaped on $\mathrm{m} 3$ and broad $\mathrm{V}$-shaped on $\mathrm{m} 2$. The posterior lingual valley is broad $\mathrm{V}$-shaped on $\mathrm{m} 1$ whilst the anterior one is not observable. Lingual cingula are absent (Fig. 3).

Comparisons: Lower teeth morphology is quite conservative in Pliocene Rhinocerotini and only a combination of characters can be useful to distinguish among the different species. Vestibular and lingual cingula are absent on Pliorhinus miguelcrusafonti (Guérin and Santafé-Llopis 1978). The lingual valleys on the lower molars of P. miguelcrusafonti are $\mathrm{V}$-shaped and the vestibular groove is narrower and deeper than in the studied specimen. In Stephanorhinus etruscus a lingual cingulum occurs sometimes on the lower teeth, whilst the vestibular cingulum is normally present (Guérin 1980, 2004). According to Lacombat (2003), distal and mesial cingula are absent on the lower molars of S. etruscus. In $S$. etruscus the vestibular groove is normally opened and shallow, and the metalophid is short, as observed in different specimens from Upper Valdarno (Italy, Early Pleistocene: IGF, NMB) and Senèze (France, Early Pleistocene; MNHN, NMB). Concerning Stephanorhinus jeanvireti, Guérin (1980) did not list useful characters to distinguish this taxon from the other Pliocene species, he only reported a description of the lingual valleys (Guérin 1980: p. 467). On the mandible from Vialette (ML V377), the vestibular grove and the lingual valleys on the molars are narrower in respect to those on the studied specimen; further the trigonid forms an acute dihedron in occlusal view. On S. jeanvireti from Monte San Pietro (MGGC) and Capannoli (IGF) the occlusal surface of molars displays a deeper vestibular groove and a shorter metalophid compared to that on the studied specimen, as well as a trigonid forming an acute dihedron. On the lower teeth of $S$. jeanvireti from Montopoli (IGF) the vestibular groove is narrower than in the studied specimen and it does not reach the neck. The morphology of the studied molars closely resembles the $\mathrm{m} 3$ from Baccinello V3 (Pandolfi and Rook 2017) and several molars from Montpellier (MN14, France; NMB, NHMUK) assigned to Pliorhinus megarhinus. In particular, the absence of developed vestibular cingulum, the shape of the vestibular groove (opened and shallow), the broad posterior lingual valleys, the long hypolophid and the obtuse trigonid are shared between the studied specimen and the studied sample of P. megarhinus. The length of the molar row, as well as the measurements of the single molars, falls within the range size of P. megarhinus (Fig. 4; Table 1; Supplementary table) being larger than the other Pliocene European species (Table 1). Furthermore, 
Fig. 4 Box-plots of the Lbm (length of the molar row in $\mathrm{mm}$ ) for the species considered in this work and the specimen from Vera Basin (MGUV 39018). The dataset is reported in Table 1

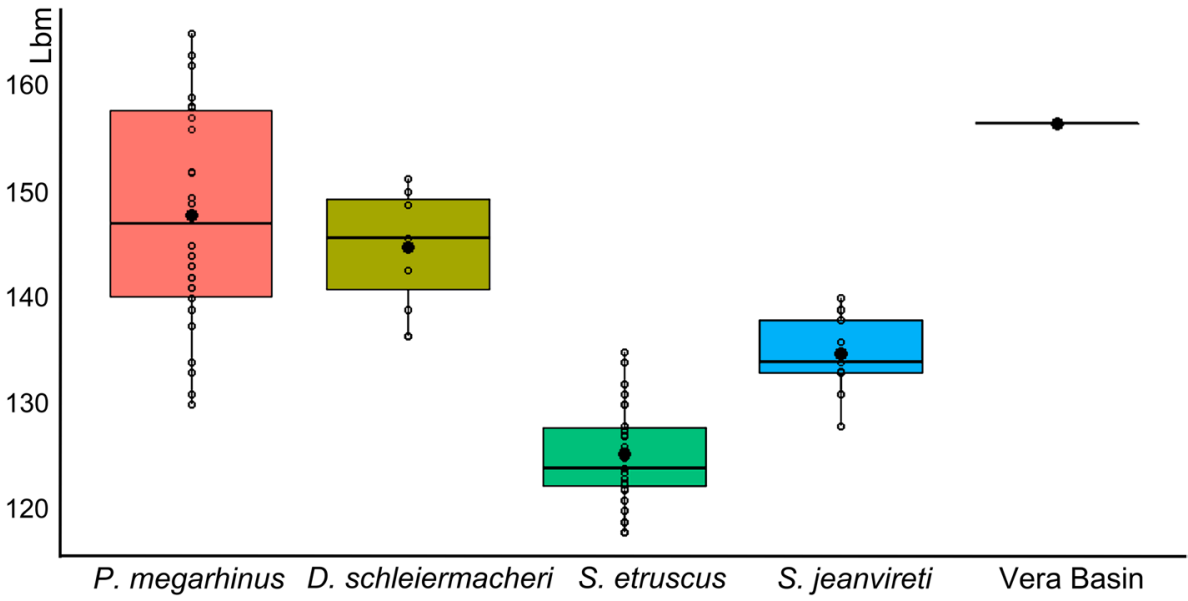

the Miocene Dihoplus schleiermacheri differs from the studied specimen by having a shorter trigonid, and V-shaped lingual valleys. The hypolophid on the molars of $D$. schleiermacheri is shorter than that on the specimens from Vera Basin and P. megarhinus. Contrary to the studied material, the entoconid on $\mathrm{m} 2 \mathrm{~s}$ and $\mathrm{m} 3 \mathrm{~s}$ of $D$. schleiermacheri from Eppelsheim is usually constricted.

\section{Discussion}

\section{Morphology and morphometry of the lower teeth in Pliocene Rhinocerotidae}

The mandibular fragment from the Vera Basin differs from the Pliocene European rhinoceroses belonging to Stephanorhinus (S. etruscus and S. jeanvireti) and to P. miguelcrusafonti, and it is morphologically and morphometrically closer to $P$. megarhinus. A few characters only can be considered as morphologically useful to distinguish among the Pliocene species due to the conservative traits displayed by this group of Rhinocerotidae.

The comparison with S. etruscus is here mainly based on the material collected from the Upper Valdarno type area and coeval sites. The lower teeth of this species can display a lingual cingulum and the vestibular groove is normally open and shallow. The molar toothrows of the Etruscan rhino considered in this work are shorter than that of the studied specimen, yet than the other Pliocene considered species. This morphometric value represents therefore a useful distinguishing character among the Pliocene rhinoceroses and in particular to discard the occurrence of the Etruscan rhinoceros in the Vera Basin and in other early and midPliocene localities.

Stephanorhinus jeanvireti is larger than the Etruscan rhinoceros but its dimensions are sometimes close or slightly smaller than P. megarhinus. The molar lengths of
S. jeanvireti, here calculated on the material from Vialette, Milia and several Italian localities, is intermediate between S. etruscus and P. megarhinus and smaller than the specimen from Vera Basin (Fig. 4). A few morphological characters of the lower teeth can be taken into account to distinguish this species from the studied material: the shape of the lingual valleys, the depth of the external groove and the shape of the trigonid.

Pliorhinus miguelcrusafonti is poorly known, being documented by a few specimens. The diagnostic features detectable on the lower teeth of this taxon are the absence of cingula on the vestibular and lingual side, the narrow V-shaped lingual valleys and the narrow and deep vestibular groove. Morphometric features of the lower teeth are included within those of other Pliocene taxa such as $S$. jeanvireti and cannot be considered for a certain taxonomic attribution.

Pliorhinus megarhinus is well-distinguishable from the other Pliocene species, notably by its larger dimensions. Anyway, small representatives of this taxon are close in size to S. jeanvireti. Pliorhinus megarhinus has wider lingual valleys in respect to the other considered taxa and, in addition, it is characterized by a long hypolophid, a shallow vestibular groove and a less angular trigonid. The presence of these characters combined with the size of the specimens are useful for a certain attribution of some remains as it is the case of the Vera Basin specimen. A resuming table of the main diagnostic features here considered for each taxon is reported in the Table 2.

\section{The Spanish Pliocene records revised: biochronology and paleobiogeography}

Stephanorhinus etruscus is a relatively well-known Early Pleistocene species, documented also from some latest Pliocene localities (Pandolfi et al. 2017). This taxon is generally smaller in size than the other Plio-Pleistocene species. However, its morphological distinguishing 
Table 2 Main morphological distinguish characters for the lower teeth of Pliocene Western European Rhinocerotidae considered in this paper

\begin{tabular}{|c|c|c|c|c|c|c|c|}
\hline Lower molars & Buccal cingulum & Lingual cingulum & Lingual valleys & Trigonid & Metalophid & Entoconid & External groove \\
\hline P. megarhinus & Absent & Absent & Mainly U-shaped & Obtuse & Long & Not constricted & Shallow \\
\hline $\begin{array}{l}\text { P. miguelcrusa- } \\
\text { fonti }\end{array}$ & Absent & Absent & V-shaped & Acute dihedron & Long & Not constricted & Deep \\
\hline D. schleiermacheri & Rarely present & Absent & $\begin{array}{l}\text { Normally } \\
\text { V-shaped }\end{array}$ & Obtuse & Short & Constricted & Deep \\
\hline S. etruscus & Usually present & $\begin{array}{l}\text { Sometimes } \\
\text { present }\end{array}$ & Mainly V-shaped & Obtuse & Short & Not constricted & Shallow \\
\hline S. jeanvireti & Usually absent & Absent & V-shaped & Acute dihedron & Short & Not constricted & Deep \\
\hline
\end{tabular}

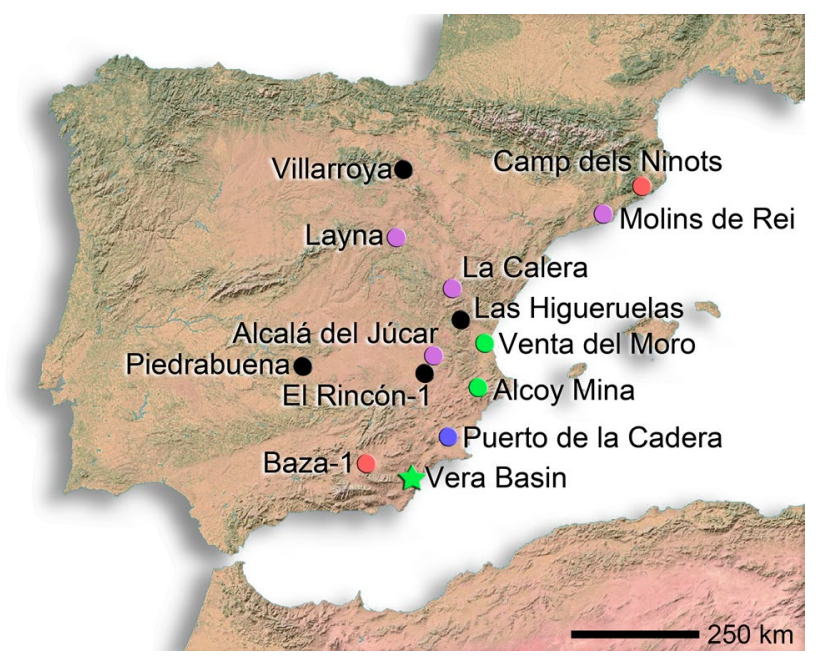

Fig. 5 Geographical map showing the Spanish Pliocene localities discussed in the text and listed in Table 2. Black circle $=S$. etruscus; Purple circle $=P$. miguelcrusafonti; Green circle $=P$. megarhinus; other colors correspond to indeterminate attribution. Interactive map is available as Supplementary File

features, in particular on teeth and postcranials, are still partially discussed, raising doubts concerning the attribution of some latest Early Pleistocene remains (Pandolfi et al. 2017). S. etruscus occurred in the Iberian Peninsula during the latest Pliocene (MN16) as recently revised in Pandolfi et al. (2017). Remains attributable to this taxon are from Las Higueruelas (Ciudad Real Province, ca. 3.3 Ma; Mazo 1995), Piedrabuena (Ciudad Real Province, MN15-MN16 transition; Mazo 1999) and El Rincón-1 (Albacete Province, MN16; Alberdi et al. 1997) (Fig. 5; Table 3). The first occurrence of the Etruscan rhinoceros is biochronologically coeval with that from sites in Italy and in the Dacian Basin, between 3.5 and 3.0 Ma (Pandolfi et al. 2017). The origin of this taxon is still unknown, and the hypothesis proposed by Heissig (1996) on a phyletic relationship with $D$. pikermiensis cannot be ruled out albeit still in the need to be confirmed by further evidence. The occurrence of the Etruscan rhinoceros would represent the faunal renewal that occurs in Europe at the Ruscinian-Villafranchian transition.

Stephanorhinus jeanvireti was named by Guérin (1972) on some cranial and postcranial material from Vialette (around $3 \mathrm{Ma}$ MN16a; France); the author also recorded this taxon in several other European localities biochronologically placed in MN16a and b (Guérin 1972, 1980; Pandolfi et al. 2019). Despite the name of this species was recently disputed (Pandolfi et al. 2019), several authors agreed to accept the Guérin's name for nomenclatural stability (see Geraads et al. 2020). In Spain S. jeanvireti has been dubitatively recorded in the Guadiz-Baza depression, at Baza-1 (Stephanorhinus cf. S. jeanvireti; around 4.0-4.5 Ma: RosMontoya et al. 2017). The rhinoceros material from Baza-1 is scarce and not highly diagnostic, being represented by two isolated lower molars and a metapodial fragment. Accordingly, a generic attribution of this material could be at present reasonable, pending the discovery of additional specimens, even if the morphology of the $\mathrm{m} 2$ (Ros-Montoya et al. 2017: Fig. 7A) closely resembles $P$. megarhinus in having a U-shaped lingual valley, a long metalophid and an obtuse trigonid. Stephanorhinus cf. jeanvireti has also been reported at Camp dels Ninots (Girona; MN16a; Gómez de Soler et al. 2012). The taxon is there represented by partially complete skeletons but they have been never described in detail, so it is difficult to verify the correct attribution of these specimens. Pending the systematic description of the material from Camp dels Ninots, the presence of $S$. jeanvireti in Spain is not confirmed here, even if its occurrence during the MN16a would be in agreement with its record in several other European areas (France, Italy, Romania: Pandolfi et al. 2019).

The rhinoceros from Layna was described by Guérin and Santafé-Llopis (1978) as a new species: Dicerorhinus miguelcrusafonti. The taxon was dubitatively retained within Stephanorhinus following the proposal of Cerdeño (1992) but it has been recently referred to the genus Pliorhinus (Pandolfi et al. 2021). The species was recorded at La Calera (Teruel) and Alcalá del Júcar (Albacete) (Cerdeño 1992; Mazo 1997), based on a few isolated postcranial remains (Table 3 ). The postcranial material described and 
Table 3 Spanish Pliocene rhinocerotine records discussed in the text with the revised identification here proposed (List of localities updated and modified from Geraads et al. 2020)

\begin{tabular}{|c|c|c|c|c|c|c|c|}
\hline Lat & Lon & Locality & Age & $\mathrm{Ma}$ & Main references & $\begin{array}{l}\text { Previous identifica- } \\
\text { tion }\end{array}$ & Revised identification \\
\hline 39.19 & -1.43 & Alcalá del Júcar & MN15 & 3.5 Ma & Mazo (1997) & $\begin{array}{l}\text { Stephanorhinus } \\
\text { miguelcrusafonti }\end{array}$ & $\begin{array}{l}\text { Pliorhinus miguel- } \\
\text { crusafonti }\end{array}$ \\
\hline 38.7 & -0.53 & Alcoy Mina & MN14 & & Montoya et al. (2006) & "Dihoplus" sp. & Pliorhinus megarhinus \\
\hline 37.48 & -2.81 & Baza-1 & MN14 & $4-4.5 \mathrm{Ma}$ & $\begin{array}{l}\text { Ros-Montoya et al. } \\
\text { (2017) }\end{array}$ & $\begin{array}{l}\text { Stephanorhinus sp. } \\
\text { cf. S. jeanvireti }\end{array}$ & Stephanorhinus? \\
\hline 41.83 & 2.82 & Camp del Ninots & MN16a & $3.2 \mathrm{Ma}$ & $\begin{array}{l}\text { Gómez de Soler et al. } \\
\text { (2012) }\end{array}$ & $\begin{array}{l}\text { Stephanorhinus cf. } \\
\text { jeanvireti }\end{array}$ & Stephanorhinus? \\
\hline 38.917 & -1.633 & El Rincón-1 & MN16b & & Alberdi et al. (1997) & $\begin{array}{l}\text { Stephanorhinus } \\
\text { etruscus }\end{array}$ & $\begin{array}{l}\text { Stephanorhinus } \\
\text { etruscus }\end{array}$ \\
\hline 40.26 & -1.06 & La Calera & MN15 & $4 \mathrm{Ma}$ & Cerdeño (1992) & $\begin{array}{l}\text { "Stephanorhinus" } \\
\text { miguelcrusafonti }\end{array}$ & $\begin{array}{l}\text { Pliorhinus miguel- } \\
\text { crusafonti }\end{array}$ \\
\hline 39.78 & -0.87 & Las Higueruelas & MN16a & $3.3-3.1 \mathrm{Ma}$ & Mazo (1995) & $\begin{array}{l}\text { Stephanorhinus } \\
\text { etruscus }\end{array}$ & $\begin{array}{l}\text { Stephanorhinus } \\
\text { etruscus }\end{array}$ \\
\hline 41.05 & -2.19 & Layna & MN15 & $3.5-3.4 \mathrm{Ma}$ & $\begin{array}{l}\text { Guérin and Santafé } \\
\text { (1978) }\end{array}$ & $\begin{array}{l}\text { "Stephanorhinus" } \\
\text { miguelcrusafonti }\end{array}$ & $\begin{array}{l}\text { Pliorhinus miguel- } \\
\text { crusafonti }\end{array}$ \\
\hline 41.41 & 2.03 & Molins de Rei & Late Pliocene & & $\begin{array}{l}\text { García-Fernández } \\
\text { (2000) }\end{array}$ & $\begin{array}{l}\text { Stephanorhinus } \\
\text { megarhinus }\end{array}$ & $\begin{array}{l}\text { Pliorhinus miguel- } \\
\text { crusafonti }\end{array}$ \\
\hline 39.02 & -4.1 & Piedrabuena & MN16a & & $\begin{array}{l}\text { Mazo and Torres } \\
\text { (1990) }\end{array}$ & $\begin{array}{l}\text { Stephanorhinus } \\
\text { etruscus }\end{array}$ & $\begin{array}{l}\text { Stephanorhinus } \\
\text { etruscus }\end{array}$ \\
\hline 37.91 & -1.15 & Puerto de la Cadena & MN14 & 4.997-4.896 Ma & Piñero et al. (2017) & $\begin{array}{l}\text { Dihoplus schleier- } \\
\text { macheri/megarhi- } \\
\text { nus }\end{array}$ & Dihoplus? \\
\hline 39.4 & -0.4 & Venta del Moro & MN13-14 & & Cerdeño (1992) & $\begin{array}{l}\text { Dihoplus schleier- } \\
\text { macheri }\end{array}$ & Pliorhinus megarhinus \\
\hline 37.29 & -1.88 & Vera Basin & Early Pliocene & & This work & Rhinocerotidae indet & Pliorhinus megarhinus \\
\hline 42.08 & -2.04 & Villarroya & MN16a & & Cerdeño (1993) & $\begin{array}{l}\text { Stephanorhinus } \\
\text { etruscus }\end{array}$ & $\begin{array}{l}\text { Stephanorhinus } \\
\text { etruscus }\end{array}$ \\
\hline
\end{tabular}

documented by Cerdeño (1992) and Mazo (1997) is morphometrically and morphologically close to the type material of P. miguelcrusafonti from Layna, thus confirming the occurrence of this taxon in the two above mentioned localities. According to Cerdeño (1992), there are a few morphological differences between this species and P. megarhinus, and the Spanish species could possibly be a subspecies of the latter. In our opinion, the morphological and morphometric differences between P. megarhinus and P. miguelcrusafonti are consistent with a specific differentiation, but the two species are phylogenetically related (Pandolfi et al. 2021). Considering its restricted geographic and biochronological distribution, P. miguelcrusafonti represents a useful marked for correlation among Pliocene Spanish faunas.

A typical Miocene taxon, Dihoplus schleiermacheri has been also reported in Spain during the early Pliocene. A few isolated teeth from Alcoy Mina have been referred to this species by Guérin (1980) and recently by Montoya et al. (2006) who assigned this locality to MN14. D. schleiermacheri has been also reported at Venta del Moro (Turolian-Ruscinian transition) (Guérin 1980; Cerdeño 1992). In agreement with Montoya et al. (2006; Fig. 13), the lower teeth from Alcoy Mina resemble those from Venta del Moro and belong to the same taxon (Table 3). The teeth from both localities resemble those from Vera Basin and P. megarhinus rather than D. schleiermacheri in having a wide lingual valley and a long metalophid in particular on the $\mathrm{m} 3$ (Montoya et al. 2006; Fig. 13G). In addition, the almost complete mandible from Venta del Moro (MNCN10977) displays a short symphyseal area, and clearly lacks the large i2 alveoli that characterize the mandibles of $D$. schleiermacheri. The molars on the mandible from Venta del Moro are much worn, but they display an open and shallow vestibular groove and lack of the entoconid constriction. Dihoplus schleiermacheri/megarhinus has been recently listed within the faunal remains collected at Puerto de la Cadena (Murcia region; MN14) (Piñero et al. 2017). The rhinoceros material is here represented by a fragment of a relatively worn lower molar (Piñero et al. 2017; Fig. 7E) and a fragment of symphysis (Piñero et al. 2017; Fig. 7A). The material from Puerto de la Cadena can be cautiously assigned to Dihoplus? pending the discovery of additional well-preserved specimens. Accordingly, the presence of D. schleiermacheri in Spain during the Pliocene is at present discarded. 


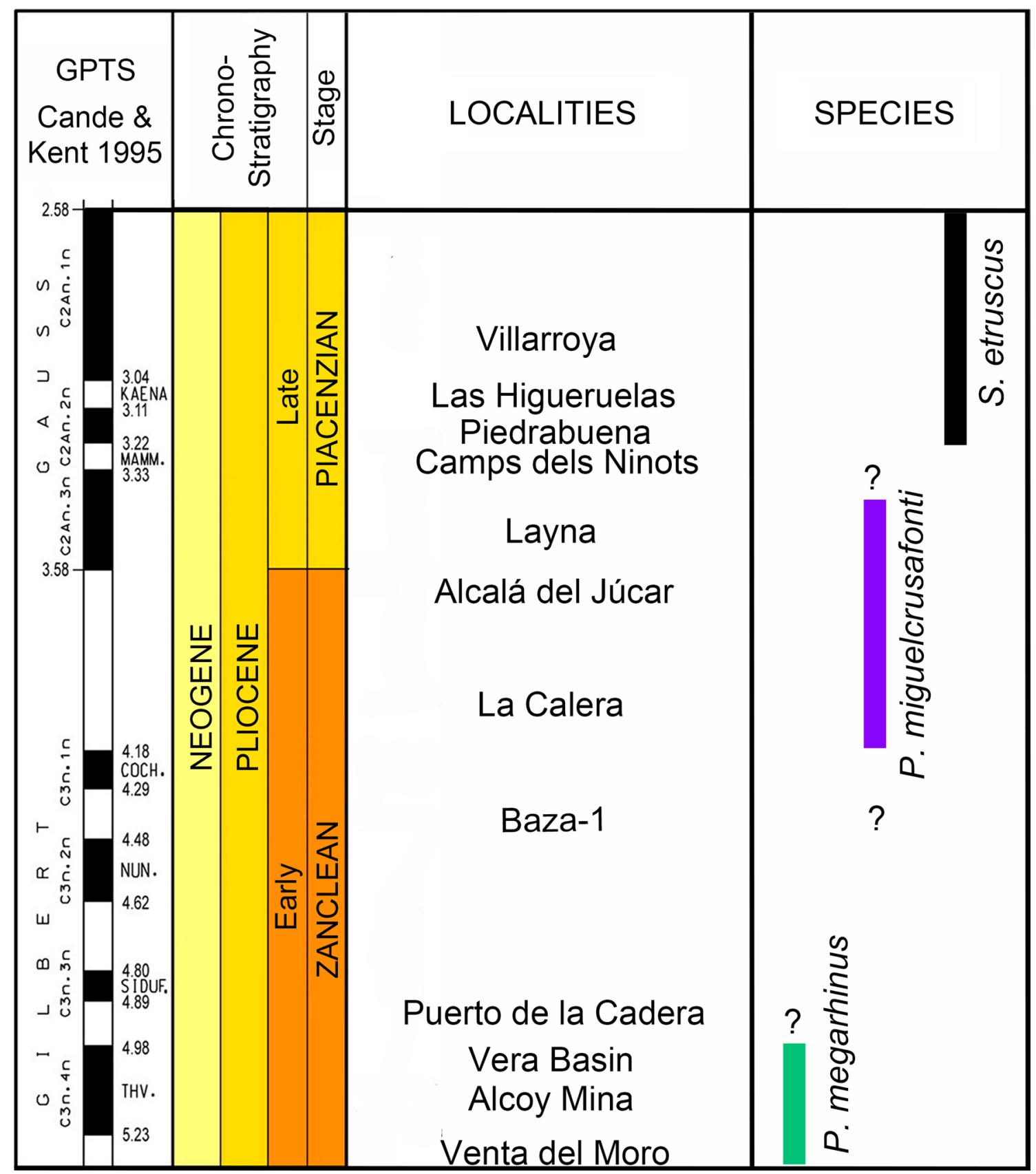

Fig. 6 New biochronological scheme for the Spanish Pliocene rhinocerotines (Table 1 for references)

Pliorhinus megarhinus is commonly documented in several early Pliocene localities of Europe, and it has been also reported in uppermost Miocene deposits (Pandolfi and Rook 2017). In Spain this taxon was previously documented at Molins de Rei (Table 3), based on a proximal epiphysis of metatarsal IV (Fernández 2000). Anyway, the bone there collected is morphologically close to P. miguelcrusafonti from Layna than to the typical $P$. megarhinus from Montpellier, being the proximal articular surface less developed than the proximal epiphysis (observations at MNCN, NMB). Thus, we provisionally re-assigned this specimen to the Layna species. Accordingly, in Spain P. megarhinus is only recorded in Vera Basin, Alcoy Mina and Venta del Moro (Fig. 5). The two first localities are referred to MN14, whilst Venta del Moro is biochronologically placed between the latest Turolian and the early Ruscinian (Table 3). The occurrence of $P$. megarhinus during that time agrees with the records of this species in France, Italy and Hungary (Pandolfi et al. 2015, 2016; Pandolfi and Rook 2017). A dispersal of this taxon from East to West Europe during the latest Miocene has been 
indeed proposed by Pandolfi et al. $(2015,2016)$ and Pandolfi and Rook (2017) who recorded P. megarhinus in several MN13 localities. The species probably reached the Iberian Peninsula at the Turolian-Ruscinian transition and occurred there till the mid-Pliocene (MN14-15 transition) (Fig. 6).

\section{Conclusions}

The systematic study of the rhinoceros specimen collected from the early Pliocene deposits of the Vera Basin is here assigned to Pliorhinus megarhinus. The morphometrical comparison reveals that this taxon is larger than $S$. etruscus and $S$. jeanvireti but overlaps with Dihoplus schleiermacheri.

Pliorhinus megarhinus and D. schleiermacheri differ in some characters of the lower molars, such as the length of the metalophid and the shape of the trigonid in occlusal view, thus allowing new considerations on the Pliocene Spanish rhinocerotine record. According to the results here obtained, three species are at least documented in Span during the Pliocene: P. megarhinus, recorded in the Vera Basin, Alcoy Mina and Venta del Moro, from the latest Turolian and the early Pliocene; P. miguelcrusafonti, recorded at Layna, La Calera, Molins de Rei and Alcalá del Júcar, midPliocene in age; and S. etruscus, recorded at Las Higueruelas, Piedrabuena and El Rincón-1, all referred to the latest Pliocene. The presence of $S$. jeanvireti has to be verified and confirmed by a detailed study of the remains from Camp dels Ninots whilst the specimen from Baza-1 cannot be attributed to a species. The presence of Dihoplus schleiermacheri as a relict taxon in Spain is not confirmed here, being the specimens from Alcoy Mina re-assigned to P. megarhinus.

The present contribution represents a new insight into the biochronology and systematics on Pliocene rhinocerotines from Spain and represents the first attempt to clarify the occurrences and dispersal of this group in the Iberian Peninsula during the Pliocene.

Supplementary Information The online version contains supplementary material available at https://doi.org/10.1007/s12542-022-00607-9.

Acknowledgements We thank two Reviewers, A. Athanassiou and R. Schellhorn, the Associate Editor T. Mörs, and the Editor-in-Chief M. Reich for their suggestions, comments and advice that greatly improved this manuscript. L.P. thanks all the curators of the mentioned institutions and museums for their support and access to the collections. Paleo[Fab]Lab thanks TBNET SOLUZIONI 3D (Arezzo) for their support and kind availability. This work is part of the "Augusto Azzaroli (1921-2015) centennial papers" by the Vertebrate Paleontology Group at the Earth Sciences Department, University of Florence.

Funding Open Access funding by University of Florence. L.P. thanks the European Commission's Research Infrastructure Action, EUSYNTHESYS project AT-TAF-2550, DE-TAF-3049, GB-TAF-2825, HU-TAF-3593, HU-TAF-5477, ES-TAF-2997; part of this research received support from the SYNTHESYS Project http://www.synth esys.info/ which is financed by European Community Research Infrastructure Action under the FP7 "Capacities" Program. This paper has been developed within the research project "Ecomorphology of fossil and extant Hippopotamids and Rhinocerotids" granted to L.P. by the University of Florence ("Progetto Giovani Ricercatori Protagonisti" initiative). This contribution is framed within a wider project on late Neogene vertebrate evolution granted with "Fondi di Ateneo" by the Earth Sciences Department of the University of Florence (L.R.). This paper has been also developed within the research project PID2019104625RB-100 and the research group RNM-200 of the Junta de Andalucía (J.S. and M.R.).

Data availability Data and material are available within the cited collections and institutions.

\section{Declarations}

Conflict of interest The authors declare that they have no conflict of interest.

Ethics approval Not applicable.

Consent to participate Not applicable.

Consent for publication Not applicable.

Open Access This article is licensed under a Creative Commons Attribution 4.0 International License, which permits use, sharing, adaptation, distribution and reproduction in any medium or format, as long as you give appropriate credit to the original author(s) and the source, provide a link to the Creative Commons licence, and indicate if changes were made. The images or other third party material in this article are included in the article's Creative Commons licence, unless indicated otherwise in a credit line to the material. If material is not included in the article's Creative Commons licence and your intended use is not permitted by statutory regulation or exceeds the permitted use, you will need to obtain permission directly from the copyright holder. To view a copy of this licence, visit http://creativecommons.org/licenses/by/4.0/.

\section{References}

Alberdi, M.T., E. Cerdeño, N. López Martínez, J. Morales, and D. Soria. 1997. La fauna Villafranquiense de El Rincón-1 (Albacete, Castilla-La Mancha). Estudios Geológicos 53 (1-2): 69-93.

Cerdeño, E. 1992. Spanish Neogene rhinoceroses. Palaeontology 35 (2): 297-308.

Cerdeño, E. 1993. Remarks on the spanish Plio-Pleistocene Stephanorhinus etruscus, Rhinocerotidae. Comptes Rendus De L'académie Des Science Paris 317: 1363-1367.

de Christol, J. 1834. Recherches sur les caractères des grandes espèces de Rhinocéros fossiles. Annales Des Sciences Naturelles, Paris 4: 44-112.

García Fernández, D. 2000. Stephanorhinus megarhinus (Rhinocerotidae) en el Plioceno de Molins De Rei, Baix Llobregat (Barcelona). Butlleti Del Centre D'estudis De La Natura Del Barcelonas-Nord 5 (1): 47-51.

Geraads, D., E. Cerdeño, D. García-Fernández, L. Pandolfi, E. Billia, A. Athanassiou, E. Albayrak, V. Codrea, T. Obada, T. Deng, H. Tong, X. Lu, S. Pícha, A. Marciszak, G. Jovanovic, D. Becker, J. Zervanova, Y. Chaïd Saoudi, A.M. Bacon, N. Sévêque, R. Patnaik, J. Březina, N. Spassov, and A. Uzunidis. 2020. A database of Old 
World Neogene and Quaternary rhino-bearing localities. http:// www.rhinoresourcecenter.com/about/fossil-rhino-database.php. Accessed 4 Nov 2021.

Gómez De Soler, B., G. Campeny Vall-Llosera, J. van der Made, O. Oms, J. Agustí, R. Sala, H.-A. Blain, F. Burjachs, J. Claude, S. García Catalán, D. Riba, and R. Rosillo. 2012. A new key locality for the Pliocene vertebrate record of Europe: The Camp dels Ninots maar (NE Spain). Geologica Acta 10 (1): 1-17.

Gray, J.E. 1821. On the natural arrangement of vertebrose animals. London Medical Repository 15: 296-310.

Guérin, C. 1972. Une nouvelle espèce de rhinocéros (Mammalia, Perissodactyla) à Vialette (Haute-Loire, France) et dans d'autres gisements du Villafranchien inférieur européen: Dicerorhinus jeanvireti n. sp. Documents Des Laboratoires De Géologie De Lyon 49: 53-150.

Guérin, C. 1980. Les Rhinocéros, (Mammalia, Perissodactyla) du Miocène terminal au Pléistocène supérieur en Europe Occidentale. Comparaison avec les espèces actuelles. Documents Des Laboratoires De Géologie De Lyon 79: 1-1185.

Guérin, C. 2004. Les rhinocéros (Mammalia, Perissodactyla) du gisement villafranchien moyen de Saint-Vallier (Drôme). Geobios 37 : 259-278.

Guérin, C., and J.V. Santafé-Llopis. 1978. Dicerorhinus miguelcrusafonti nov. sp., une nouvelle espèce de rhinocéros (Mammalia, Perissodactyla) du gisement Pliocène supérieur de Layna (Soria, Espagne) et de la formation Pliocène de Perpignan (PyrénéesOrientales, France). Geobios 11: 457-491.

Guérin, C., and E. Tsoukala. 2013. The Tapiridae, Rhinocerotidae and Suidae (Mammalia) of the Early Villafranchian site of Milia (Grevena, Macedonia, Greece). Geodiversitas 35 (2): 447-489.

Guérin, C., R. Ballesio, and H. Méon-Villain. 1969. Le Dicerorhinus megarhinus (Mammalia, Rhinocerotidae) du Pliocène de SaintLaurent-des-Arbres (Gard). Documents Des Laboratoires De Géologie De Lyon 31: 55-145.

Heissig, K. 1996. The stratigraphical range of fossil rhinoceroses in the late Neogene of Europe and Eastern Mediterranean. In The Evolution of Western Eurasian Neogene Mammal Faunas, ed. R.L. Bernor, V. Fahlbush, and H.-W. Mittman, 339-347. New York: Columbia University Press.

Lacombat, F. 2003. Étude des Rhinocéros du Pléistocène de l'Europe Méditerranéenne et du Massif Central - Paléontologie, Phylogénie et Biostratigraphie. Unpublished $\mathrm{PhD}$ thesis, 1-524. Paris: Muséum National d'Histoire Naturelle de Paris.

Lacombat, F. 2006. Morphological and biometrical differentiation of the teeth from Pleistocene species of Stephanorhinus (Mammalia, Perissodactyla, Rhinocerotidae) in Mediterranean Europe and the Massif Central, France. Palaeontographica, Abt. a. 274 (3-6): 71-111.

Lacombat, F., and T. Mörs. 2008. The northernmost occurrence of the rare Late Pliocene rhinoceros Stephanorhinus jeanvireti (Mammalia, Perissodactyla). Neues Jahrbuch Für Geologie Und Paläontologie, Abhandlungen 249 (2): 157-165.

Mazo, A.V. 1995. Stephanorhinus etruscus (Perissodactyla, Mammalia) en el Villafranquiense inferior de Las Higueruelas, Alcolea de Calatrava (Ciudad Real). Estudios Geológicos 51 (5-6): 285-290.

Mazo, A.V. 1997. El yacimiento rusciniense de Alcalá del Júcar (Albacete). Taxonomía y Biostratigrafía. Estudios Geológicos 53 (5-6): 275-286.

Mazo, A.V. 1999. Vertebrados fósiles del Campo de Calatrava (Ciudad Real). In La huella del pasado: Fósiles de Castilla_La Mancha, eds E. Aguirre, I. Rábano. Patrimonio Histórico-Arqueología Castilla - La Mancha, Junta de Comunidades de Castilla La Mancha, Toledo 16: 281-295.

Mazo, A.V., and T. Torres 1990. El yacimiento Plioceno del Pozo de Piedrabuena (Campo de Calatrava, provincia de Ciudad Real).
Geología, paleontología y análisis paleoambiental. Estudios Geologicos 47: 339-348.

Mazza, P. 1988. The Tuscan Early Pleistocene rhinoceros Dicerorhinus etruscus. Palaeontographia Italica 75: 1-87.

Montoya, P., L. Ginsburg, M.T. Alberdi, J. van der Made, J. Morales J., and M.D. Soria. 2006. Fossil large mammals from the early Pliocene locality of Alcoy (Spain) and their importance in biostratigraphy. Geodiversitas 28(1): 137-173.

Morales, J. 1984. Venta del Moro: su macrofauna de mamíferos y bioestratigrafía continental de Mioceno terminal mediterráneo. Unpublished PhD thesis, 1-340. Madrid: Universidad Complutense de Madrid.

Ott d'Estevou, P., C. Montenat, and J.C. Alvado. 1991. Le basin de Vera-Garrucha. In Les Bassins Neogenes du Domaine Bétique Oriental (Espagne). Téctonique et Sédimentation dans un Couloir de Décrochement, ed. C. Montenat, 165-187. Paris: Documents et Travaux IGAL.

Owen, R.M. 1848. Description of teeth and proportion of jawsof two extinct Anthracotherioid quadrupeds (Hyopotamus vectianus and Hyopotamus bovinus) discovered by the Marchioness of Hastings in the Eocene deposits on the NW coast of the Isle of Wight: With an attempt to develop Cuvier's idea of the classification of pachyderms by the number of their toes. Quarterly Journal of the Geological Society of London 4: 103-141.

Pandolfi, L. 2013. New and revised occurrences of Dihoplus megarhinus (Mammalia Rhinocerotidae) in the Pliocene of Italy. Swiss Journal of Palaeontology 132: 239-255.

Pandolfi, L., M. Gasparik, and I. Magyar. 2016. Rhinocerotidae from the upper Miocene deposits of the Pannonian Basin (Hungary): implications for migration routes and biogeography. Geologica Carpathica 67: 69-82

Pandolfi, L., F. Rivals, and R. Rabinovich. 2020. A new species of rhinoceros from the site of Bethlehem: 'Dihoplus' bethlehemsis sp. nov. (Mammalia, Rhinocerotidae). Quaternary International 537: 48-60.

Pandolfi, L., and H. Erten. 2017. Stephanorhinus hundsheimensis (Mammalia, Rhinocerotidae) from the late Early Pleistocene of the Denizli Basin (Anatolia). Geobios 50: 65-73.

Pandolfi, L., and L. Rook. 2017. Rhinocerotidae (Mammalia, Perissodactyla) from the latest Turolian localities (MN 13; Late Miocene) of central and northern Italy. Bollettino Della Società Paleontologica Italiana 56 (1): 45-56.

Pandolfi, L., E. Cerdeño, V. Codrea, and T. Kotsaki. 2017. Biogeography and chronology of the Eurasian extinct rhinoceros Stephanorhinus etruscus, Mammalia, Rhinocerotidae. Comptes Rendus Palevol 16: 762-773.

Pandolfi, L., P.-O. Antoine, M. Bukhsianidze, D. Lordkipanidze, and L. Rook. 2021. Northern Eurasian rhinocerotines (Mammalia, Perissodactyla) by the Pliocene-Pleistocene transition: Phylogeny and historical biogeography. Journal of Systematic Palaeontology. https://doi.org/10.1080/14772019.2021.1995907.

Pandolfi, L., V. Codrea, and A. Popescu. 2019. Stephanorhinus jeanvireti (Mammalia, Rhinocerotidae) from the early Pleistocene of Colțești, southwestern Romania. Comptes Rendus Palevol 18: 1041-1056.

Pandolfi, L., F. Grossi, and V. Frezza. 2015. New insights into the Pleistocene deposits of Monte delle Piche, Rome, and remarks on the biochronology of continental Hippopotamus (Mammalia, Hippopotamidae) and Stephanorhinus etruscus (Mammalia, Rhinocerotidae) in Italy. Estudios Geologicos 71: e026.

Piñero, P., J. Agustí, O. Oms, I. Fierro, P. Montoya, S. Mansino, F. Ruiz-Sánchez, D.M. Alba, M.T. Alberdi, H.-A. Blain, C. Laplana, J. van der Made, A.V. Mazo, J. Morales, X. Murelaga, A. PérezGarcía, F. Pérez-Valera, J.A. Pérez-Valera, P. Sevilla, J.M. Soria, and G. Romero. 2017. Early Pliocene continental vertebrate fauna at Puerto de la Cadena (SE Spain) and its bearing on the 
marine-continental correlation of the Late Neogene of Eastern Betics. Palaeogeography, Palaeoclimatology, Palaeoecology 479: 102-114.

Ros-Montoya, S., B. Martínez-Navarro, M.-P. Espigares, A. GuerraMerchán, J.M. García-Aguilar, P. Piñero, A. Rodríguez-Rueda, J. Agustí, O. Oms, and P. Palmqvist. 2017. A new Ruscinian site in Europe: Baza-1 (Baza basin, Andalusia, Spain). Comptes Rendus Palevol 16: 746-761.

Sendra, J., M. Reolid, and J. Reolid. 2020. Palaeoenvironmental interpretation of the Pliocene fan-delta system of the Vera Basin (SE Spain): Fossil assemblages, ichnology and taphonomy. Palaeoworld 29: 769-788.
Stokes, M. 2008. Plio-Pleistocene drainage development in an inverted sedimentary basin: Vera basin, Betic Cordillera, SE Spain. Geomorphology 100: 193-211.

Tsoukala, E. 2018. Rhinocerotidae from the Late Miocene and Late Pliocene of Macedonia, Greece. A revision of the Neogene-Quaternary Rhinocerotidae of Greece. Revue De Paléobiologie 37: 609-630.

Vekua, A. 1972. Kvabebi Fauna of Akchagylian Vertebrates. Moscow: Nauka (in Russian).

Völk, H.R. 1967. Zur Geologie und Stratigraphie des Neogenbeckens von Vera, Südost-Spanien. Unpublished PhD thesis, 1-164. Amsterdam: University Amsterdam. 